\title{
PENERAPAN TOKEN ECONOMY PADA SISWA DENGAN MASALAH KENAKALAN REMAJA
}

\author{
Oleh: \\ Putri Nabhani Nurany, Nandang Maulana, \& Budi M. Taftazani \\ Email : \\ putnbhn@gmail.com
}

\begin{abstract}
ABSTRAK Kenakalan remaja merupakan salah satu masalah sosial yang ada di Indonesia. Kenakalan ini bentuknya macam-macam, contohnya seperti tawuran, penyalah gunaan narkoba, seks bebas dan lain-lain. Hal ini disebabkan karena masa remaja merupakan masa yang rentan akan badai dan tekanan sehingga seorang remaja yang tidak bisa mengaktualisasikan dirinya akan melakukan perbuatan menyimpang dan membuat masalah sosial tersendiri di masyarakat.

Terdapat factor eksternal dan factor internal yang menyebabkan seorang remaja akhirnya melakukan kenalakan-kenakalan tersebut. Faktor eksternal contohnya adalah lingkungan dan teman sebaya yang tidak baik dan bisa membawa pengaruh yang tidak baik pula. Sedangkan factor internal terdapat dua poin yaitu, krisis jati diri dan ketidak mampuan remaja untuk mengontrol dirinya sendiri.

Penelitian ini dimaksudkan untuk menyoroti factor internal pada poin control diri. Sehingga yang akan dilakukan adalah melakukan pendekatan behavioral dengan melakukan pembiasaan management waktu yang baik pada remaja. Dengan begitu, diharapkan subjek penelitian yang merupakan remaja dapat mengatur waktunya dengan baik dan terhindar dari kenakalan remaja.
\end{abstract}

Kata kunci : Remaja, kenakalan, pengelolaan waktu, token economy

\section{PENDAHULUAN}

Banyak sekali permasalahan sosial yang ada di Indonesia, diantaranya adalah kenakalan remaja. Menurut Kusumanto dalam Sofyan S. Willis (2010: 89) menerangkan bahwa juvenile delinquency atau kenakalan anak ialah tingkah laku individu yang bertentangan dengan syarat-syarat dan pendapat umum yang dianggap acceptable dan baik oleh suatu lingkungan atau hukum yang berlaku disuatu masyarakat yang berkebudayaan. Menurut bentuknya, Sunarwiyati S (1985) membagi kenakalan remaja kedalam tiga tingkatan ;

1. Kenakalan biasa, seperti suka berkelahi, suka keluyuran, membolos sekolah, pergi dari rumah tanpa pamit
2. Kenakalan yang menjurus pada pelanggaran dan kejahatan seperti mengendarai mobil tanpa SIM, mengambil barang orang tua tanpa izin

3. Kenakalan khusus seperti penyalahgunaan narkotika, hubungan seks diluar nikah, pergaulan bebas, pemerkosaan dll.

\section{PEMBAHASAN}

Kenakalan-kenakalan ini sering kali dianggap hal yang wajar bagi sebagian masyarakat. Padahal jika mendapat pembiaran, kenakalan remaja ini akan menimbulkan masalah sosial yang lebih besar.

Terbukti menurut data yang dilansir dari BNN (Badan Narkotika Nasional) bahwa sejak 2010 
sampai 2013 tercatat ada peningkatan jumlah pelajar dan mahasiswa yang menjadi tersangka kasus narkoba. Pada 2010 tercatat ada 531 tersangka narkotika, jumlah itu meningkat menjadi 605 pada 2011. Setahun kemudian, terdapat 695 tersangka narkotika, dan tercatat 1.121 tersangka pada 2013. Selain itu Komnas PA mencatat, sepanjang 2013 ada 255 kasus tawuran antar-pelajar di Indonesia. Angka ini meningkat tajam dibanding tahun sebelumnya, yang hanya 147 kasus. Dari jumlah tersebut, 20 pelajar meninggal dunia, saat terlibat atau usai aksi tawuran, sisanya mengalami luka berat dan ringan. (Tribunnews.com, 21/12/2013)

Banyak sekali factor yang menjadi penyebab seorang remaja melakukan kenakalankenakalan yang meresahkan, diantaranya adalah krisis identitas dan control yang lemah terhadap diri sendiri. Hal ini berkenaan dengan apa yang dinyatakan oleh menurut Hurlock (1980) bahwa kondisi masa remaja dikenal dengan masa rentan "badai dan tekanan" (storm and stress). Masa remaja merupakan fase transisi dimana seorang manusia sudah melewati masa kanak-kanaknya namun dalam waktu yang sama belum cukup matang untuk dikatakan dewasa. Remaja berasal dari kata latin adolensence yang berarti tumbuh atau tumbuh menjadi dewasa. Istilah adolensence mempunyai arti yang lebih luas lagi yang mencakup kematangan mental, emosional sosial dan fisik (Hurlock, 1992).

Para remaja yang rata-rata duduk di bangku SMP atau SMA belum bisa untuk mengontrol dirinya untuk melakukan hal-hal positif yang berguna, karena dalam dirinya masih terdapat kebingungan akan identitas dirinya sendiri. Karena itulah, kenakalan remaja menjadi pelarian atas stress yang tidak bisa diatasi oleh para remaja tersebut.

Sebuah riset bahkan mengatakan bahwa tingkat kegelisahan siswa SMA sama dengan tingkat kecemasan pasien psikiatri pada awal tahun 50an. (https://www.psychologytoday.com/blog/anxi ety-files/200804/how-big-problem-is-anxiety)
"And anxiety has been increasing. The average high school kid today has the same level of anxiety as the average psychiatric patient in the early 1950's. We are getting more anxious every decade."

Hal ini menambah keyakinan bahwa perlu adanya perhatian lebih terhadap stress yang dialami siswa. Karena lebih jauh lagi, selain kenakaln remaja, menurut Hiew \& Glendon (Spielberger\& Sarason, 2005) dalam penelitiannya ia menyatakan bahwa stress yang dialami remaja bisa menurunkan kemampuan untuk berkembang lebih sehat, berfungsi baik dan matang pada kedewasaan.

Seperti yang sudah disinggung sebelumnya, bahwa salah satu factor penyebab terjadinya kenakalan remaja adalah lemahnya control terhadap diri sendiri. Sebagai salah satu bentuk control yang baik terhadap diri sendiri diantaranya adalah dengan melakukan menejemen waktu yang baik terhadap semua aktifitas remaja yang bersangkutan. Hal ini bisa menjadi alat yang membantu mencegah terjadinya kenakalan remaja, karena dengan menejemen waktu yang baik, para remaja tidak akan memiliki waktu untuk melakukan hal-hal yang tiddak baik bagi diri mereka. Mereka akan lebih aware terhadap pentingnya apa yang mereka lakukan sekarang demi masa depan yang cerah. Dengan menejemen waktu yang baik pula seorang remaja akan terhindar dari stress serta kecemasan karena jika waktu mereka manfaatkan dengan baik, kehidupan akan berjalan dengan baik pula, sehingga stress dan kecemasan bisa terhindarkan. Namun sayangnya perihal pentingnya menejemen waktu ini belum banyak disadari oleh para remaja, sehingga perlu adanya pendampingan yang akan mampu menjelaskan betapa menejemen waktu yang baik akan sangat berguna bagi mereka.

Pekerja sosial dalam ranah case work memiliki metode untuk membantu siswa SMA yang belum bisa melakukan management waktu. Yaitu dengan melakukan pendekatan 
behavioral dengan menggunakan teknik token economy.

Teknik ini dilakukan dengan menghunakan prinsip reward and punishment. Token economy adalah sistem perlakuan kepada tiap individu untuk mendapatkan bukti target perilaku setelah mengumpulkan sejumlah prilaku tertentu sehingga mencapai kondisi yang diharapkan. Contoh seperti pada lembar bukti prestasi. Siswa mendapatkan bukti dalam bentuk rewads atau hadiah dari pekerjaan yang dapat ditunjukannya. (Jason, 2009 ; 35). Tujuan prosedur ini adalah mengubah motivasi ekstrinsik menjadi motivasi yang intrinsik. Diharapkan bahwa perolehan tingkah laku yang diinginkan akhirnya dengan sendirinya akan menjadi cukup mengganjar untuk memelihara tingkah laku yang baru (Corey, 2003:227). Menurut Komalasari dkk (2011:167) penggunaan token sebagai reinforcer untuk membentuk tingkah laku memiliki beberapa keuntungan, antara lain: (1) token tidak mengurangi nilai insentif, terutama ketika kekuatan pemerolehan (earning power) dan nilainya meningkat sering dengan peningkatan perilaku, (2) token dapat mengurangi penundaan antara diantara tingkah laku yang diinginkan dengan hadiah (reward), (3) token dapat digunakan sebagai motivator konkrit (concrete motivator) untuk mengubah tingkah laku tertentu, (4) token adalah bentuk dari perkuatan yang positif, (5) individu memiliki kesempatan untuk menentukan bagaimana menggunakan token yang didapatkan, (6) token economy dapat mengarahkan ke peningkatan moral konseli dan staf, (7) sistem token dapat memungkinkan untuk mengukur penguatan sosial, (8) token menjadi jembatan antara institusi dan kehidupan diluar sekolah

Sebelum dilakukan teknik atau metode token economy ini, tentu harus dilakukan asesment mendalam terlebih dahulu agar peneliti bisa mengetahui masalah dan berbagai system sumber dari remaja yang akan menjadi subjek penelitian, hal itu nantinya bisa membantu peneliti untuk mengajak subjek membiasakan perilaku management waktu yang baik sesuai dengan tujuan yang telah ditentukan di awal. Seorang pekerja sosial juga harus menjelaskan pentingnya management waktu itu sendiri sebelum metode tocen economy ini diterapkan pada subjek, sehingga siswa tersebut menyadari bahwa management waktu yang baik akan membuat dirinya lebih baik pula.

Remaja didefinisikan sebagai masa peralihan dari masa anak-anak ke masa dewasa. Istilah ini menunjuk masa dari awal pubertas sampai tercapainya kematangan, biasanya mulai dari usia 14 pada pria dan usia 12 pada wanita. Batasan remaja dalam hal ini adalah usia 10 tahun s/d 19 tahun menurut klasifikasi World Health Organization (WHO)."Remaja". Kata itu menurut remaja sendiri adalah kelompok minoritas yang punya warna tersendiri, yang punya "dunia" tersendiri yang sukar dijamah oleh orang tua. Kata remaja berasal dari bahasa latin yaitu adolescere (kata bendanya, adolescentia yang berarti remaja) yang berarti "tumbuh atau tumbuh menjadi dewasa. Istilah adolescence mempunyai arti yang cukup luas: mencakup kematangan mental, emosional, sosial, dan fisik. ( Piaget ). Dengan mengatakan poin- poin sebagai berikut secara psikologis masa remaja

1. Usia dimana individu berintegrasi dengan masyarakat dewasa.

2. Usia dimana anak tidak merasa dibawah tingkat orang - orang yang lebih tua melainkan berada pada tingkatan yang sama, sekurang - kurangnya masalah hak. 3. Integrasi dalam masyarakat dewasa mempunyai banyalah aspek afektif.

4. Kurang lebih berhubungan dengan masa puber.

5. Transformasi intelektual yang khas dari cara berpikir remaja ini memungkinkan untuk mencapai integrasi dalam hubungan sosial orang dewasa.

Terdapat beberapa hal yang menjadi cirri-ciri dari seorang remaja, diantaranya : 
1. Masa remaja sebagai periode peralihan, yaitu peralihan dari masa kanak-kanak ke peralihan masa dewasa.

2. Masa remaja sebagai periode perubahan.

3. Masa remaja sebagai usia bermasalah.

4. Masa remaja sebagai masa mencari identitas.

5. Masa remaja sebagai usia yang menimbulkan ketakutan, karena masalah penyesuaian diri dengan situasi dirinya yang baru, karena setiap perubahan membutuhkan penyesuaian diri.

6. Masa remaja sebagai ambang masa dewasa.

7. Ciri-ciri kejiwaan remaja, tidak stabil, keadaan emosinya goncang, mudah condong kepada ekstrim, sering terdorong, bersemangat, peka, mudah tersinggung, dan perhatiannya terpusat pada dirinya.

Dikarenakan beberapa cirri-ciri yang sudah diungkapkan sebelumnya, hal itu menunjukan betapa remaja begitu rentan terjebak dalam kenakalan-kenakalan yang tidak bisa dibiarkan. Kenakalan remaja meliputi semua perilaku yang menyimpang dari norma-norma hukum pidana yang dilakukan oleh remaja. Perilaku tersebut akan merugikan dirinya sendiri dan orang-orang di sekitarnya. Para ahli pendidikan sependapat bahwa remaja adalah mereka yang berusia 13-18 tahun. Pada usia tersebut, seseorang sudah melampaui masa kanak-kanak, namun masih belum cukup matang untuk dapat dikatakan dewasa. Ia berada pada masa transisi.

A. Definisi kenakalan remaja menurut para ahli

Kartono, ilmuwan sosiologi "Kenakalan Remaja atau dalam bahasa Inggris dikenal dengan istilah juvenile delinquency merupakan gejala patologis sosial pada remaja yang disebabkan oleh satu bentuk pengabaian sosial. Akibatnya, mereka mengembangkan bentuk perilaku yang menyimpang".
Santrock, Kenakalan remaja merupakan kumpulan dari berbagai perilaku remaja yang tidak dapat diterima secara sosial hingga terjadi tindakan kriminal." Masalah kenakalan mulai mendapat perhatian masyarakat secara khusus sejak terbentuknya peradilan untuk anak-anak nakal (juvenile court) pada 1899 di Illinois, Amerika Serikat.

B. Jenis-jenis kenakalan remaja:

- Penyalahgunaan narkoba

- Seks bebas

- Tawuran antara pelajar

C. Penyebab terjadinya kenakalan remaja

Perilaku 'nakal' remaja bisa disebabkan oleh faktor dari remaja itu sendiri (internal) maupun faktor dari luar (eksternal).

Faktor internal:

1. Krisis identitas: Perubahan biologis dan sosiologis pada diri remaja memungkinkan terjadinya dua bentuk integrasi. Pertama, terbentuknya perasaan akan konsistensi dalam kehidupannya. Kedua, tercapainya identitas peran. Kenakalan ramaja terjadi karena remaja gagal mencapai masa integrasi kedua.

2. Kontrol diri yang lemah: Remaja yang tidak bisa mempelajari dan membedakan tingkah laku yang dapat diterima dengan yang tidak dapat diterima akan terseret pada perilaku 'nakal'. Begitupun bagi mereka yang telah mengetahui perbedaan dua tingkah laku tersebut, namun tidak bisa mengembangkan kontrol diri untuk bertingkah laku sesuai dengan pengetahuannya.

Faktor eksternal:

1. Keluarga dan Perceraian orangtua, tidak adanya komunikasi antar anggota keluarga, atau perselisihan antar anggota keluarga bisa memicu perilaku negatif pada remaja. Pendidikan yang salah di keluarga pun, seperti terlalu memanjakan 
anak, tidak memberikan pendidikan agama, atau penolakan terhadap eksistensi anak, bisa menjadi penyebab terjadinya kenakalan remaja.

2. Teman sebaya yang kurang baik

3. Komunitas/lingkungan tempat tinggal yang kurang baik

Peneliti disini ingin mengetahui apakah kenakalan remaja tersebut bisa dicegah atau dikendalikan dengan cara lebih mengatur waktu remaja yang bersangkutan sehingga dia bisa terhindar-hindar dari faktor-faktor baik internal maupun eksternal yang menyebabkan kenakalan remaja. Apalagi seperti yang telah diungkapkan sebelumnya bahwa salah satu factor internal terjadinya kenakalan remaja adalah karena control diri yang lemah.

Menurut Kamus Besar Bahasa Indonesia, manajemen adalah penggunaan sumber daya secara efektif untuk mencapai sasaran. Dalam Kamus Besar Bahasa Indonesia, waktu merupakan seluruh rangkaian saat ketika proses, perbuatan, atau keadaan berada atau berlangsung. Manajemen waktu adalah menyelesaikan sesuatu dengan lebih cepat dan bekerja lebih cerdas (Davidson, 2001, h.6). menurut Orr (dalam Saputro, 2006, h. 21), manajemen waktu diartikan sebagai penggunaan waktu seefisien dan seefektif mungkin untuk memperoleh waktu maksimal. Taylor (1990, h. 9) mengatakan bahwa manajemen waktu adalah pencapaian sasaran utama kehidupan sebagai hasil utama kehidupan sebagai hasil dari menyisihkan kegiatan-kegiatan yang tidak berarti yang sering memakan banyak waktu. Dari beberapa pengertian di atas dapat disimpulkan bahwa manajemen waktu adalah proses pencapaian suatu sasaran atau tujuan tertentu yang telah ditentukan dalam kurun waktu tertentu dengan menggunakan sumber daya secara efektif dan efisien, seperti manusia, uang, perlengkapan, bahan-bahan, dan metode-metode tertentu serta dengan menyisihkan kegiatanya

Kegiatan mengubah perilaku seseorang dari yang awalnya tidak bisa mengendalikan waktu sehingga menjadi lebih teratur waktunya bisa disebut dengan behavioral therapy. Dilansir dari website http://www.psychologistanywhereanytime.co $\underline{m}$ pada tanggal 13 Oktober 2014, yang dimaksud dengan therapy behavioral adalah:

"Behavioral therapy, often referred to as behavior modification, is a therapeutic approach of altering a person's behaviors and reactions through positive and negative reinforcement. A simple example of positive reinforcement in behavior modification is providing compliments, approval, encouragement, and affirmation"

Sumber lain mengatakan bahwa behaviorisme adalah satu pandangan teoritis yang beranggapan, bahwa persoalan psikologi adalah tingkah laku, tanpa mengaitkan konsepsi-konsepsi mengenai kesadaran dan mentalitas(JP.Chaplin, 2002:54). Aliran Behaviorisme ini berkembang pada mulanya di Rusia kemuadian diikuti perkembangannya di Amerika oleh JB. Watson (1878-1958). Aliran Behaviorisme menolak metode introspeksi darialiran strukturalisme dengan sebuah keyakinan bahwa menurut para behaviorist metode introspeksi tidak dapat menghasilkan data yang objektif, karena kesadaran menurut para behaviorist adalah sesuatu yang Dubios, yaitu sesuatu yang tidak dapat diobservasi secara langsung, secara nyata (Walgito,2002:53). Bagi aliran Behaviorisme yang menjadi focus perhatian adalah perilaku yang tampak, karena persoalan psikologi adalah tingkah laku, tanpa mengaitkan konsepsi-konsepsi mengenai kesadaran dan mentalitas. Pada awalnya behaviorisme lahir di Rusia dengan tokohnya Ivan Pavlov, namun pada saat yang hamper bersamaan di Amerika behaviorisme muncul dengan salah satu tokoh utamanya John B. Watson.

Salah satu strategi behavioral therapy adalah dengan menggunakan token economy. Token economy adalah sistem perlakuan kepada tiap individu untuk mendapatkan bukti target 
perilaku setelah mengumpulkan sejumlah prilaku tertentu sehingga mencapai kondisi yang diharapkan. Contoh seperti pada lembar bukti prestasi. Siswa mendapatkan bukti dalam bentuk rewads atau hadiah dari pekerjaan yang dapat ditunjukannya. (Jason, 2009 ; 35).

Token Economy merupakakan sistem perlakuan pemberian penghargaan yang diwujudkan secara visual. Token Economy adalah usaha mengembangkan prilaku sesuai dengan tujuan yang diharapkan melalui penggunaan penghargaan. Setiap individu mendapat penghargaan setelah menunjukan prilaku yang diharapkan. Hadiah dikumpul selanjutnya setelah hadiah terkumpul ditukar dengan penghargaan yang bermakna. (Joson, 2009 ; 66). Komponen yang dibutuhkan, di antaranya adalah token atau simbol praktis dan atraktif untuk memicu tumbuhnya motivasi belajar. Yang dapat digunakan sebagai simbol penghargaan seperti stiker, guntingan kertas, simbol bintang, atau uang mainan. Token sendiri tidak selalu dalam bentuk yang berharga, namun setelah klien mengoleksinya setelah menunjukan prilaku yang diharapkan mereka dapat menukarkan token itu dengan sesuatu yang berharga.

\section{PENUTUP}

Kenakalan remaja merupakan salah satu masalah sosial yang ada di Indonesia. Kenakalan ini bentuknya macam-macam, contohnya seperti tawuran, penyalah gunaan narkoba, seks bebas dan lain-lain. Hal ini disebabkan karena masa remaja merupakan masa yang rentan akan badai dan tekanan sehingga seorang remaja yang tidak bisa mengaktualisasikan dirinya akan melakukan perbuatan menyimpang dan membuat masalah sosial tersendiri di masyarakat.

Terdapat factor eksternal dan factor internal yang menyebabkan seorang remaja akhirnya melakukan kenalakan-kenakalan tersebut. Faktor eksternal conothnya adalah lingkungan dan teman sebaya yang tidak baik dan bisa membawa pengaruh yang tidak baik pula. Sedangkan factor internal terdapat dua poin yaitu, krisis jati diri dan ketidak mampuan remaja untuk mengontrol dirinya sendiri.

Penelitian ini dimaksudkan untuk menyoroti factor internal pada poin control diri. Sehingga yang akan dilakukan adalah melakukan pendekatan behavioral dengan melakukan pembiasaan management waktu yang baik pada remaja. Dengan begitu, diharapkan subjek penelitian yang merupakan remaja dapat mengatur waktunya dengan baik dan terhindar dari kenakalan remaja.

\section{DAFTAR PUSTAKA}

http://harianterbit.com/read/2014/09/13/8219/ 29/18/22-Persen-Pengguna-NarkobaKalangan-Pelajar

http://belajarpsikologi.com/kenakalan-remaja/ http://staff.uny.ac.id/sites/default/files/tmp/Mi crosoft \%20Word\%20\%20KENAKALAN\%20REMAJA_P ENYEBAB\%20DAN\%20SOLUSI. pdf

http://eprints.umk.ac.id/1014/3/BAB_II.pdf

http://www.tribunnews.com/nasional/2013/12 /21/tahun-ini-20-pelajar-indonesiatewas-karena-tawuran

http://ejournal.undiksha.ac.id/index.php/JJBK /article/view/3652/2940

http://www.academia.edu/8529626/psikologi Perkembangan_Remaja

http://www.academia.edu/9778890/Pengertia n_Manajemen_Waktu 